\title{
Editorial: Advances in Road Safety Planning
}

\author{
Krzysztof Goniewicz $^{1 *}$ and Dorota Lasota ${ }^{2}$ \\ ${ }^{1}$ Department of Aviation Security, Military University of Aviation, Deblin, Poland, ${ }^{2}$ Department of Experimental and Clinical \\ Pharmacology, Medical University of Warsaw, Warsaw, Poland
}

Keywords: road safety, traffic accidents, road traffic accident, traffic safety (TS), healthy transport

\section{Editorial on the Research Topic}

\section{Advances in Road Safety Planning}

The concept of Healthy transport embraces many diverse areas, spanning from road safety, and traffic security, to environmental sustainability as well as human behavior and health.

The present collection includes papers that touch upon international experiences concerning traffic safety issues, and that address the relation between traffic safety and various factors that impact safety such as: road networks' engineering, management and control of the traffic system, planning and strategies, transportation systems, citizens' education, knowledge, and behavior.

Traffic Safety has been internationally recognized as a primary strategic goal in many societies (Najaf et al., 2017; Pauer, 2017). Traffic safety concept is not limited to the reduction of road accidents. Traffic safety should be considered as a national issue as it is strongly related to all aspects of life and has a close link with the protection and sustenance the natural environment (Pawłowski et al., 2019).

Increasing traffic safety is an important political and social goal. Road safety comprises the three

Edited and reviewed by: James Evans,

The University of Manchester, United Kingdom

*Correspondence: Krzysztof Goniewicz k.goniewicz@law.mil.pl

Specialty section:

This article was submitted to Governance and Cities, a section of the journal Frontiers in Sustainable Cities

Received: 13 January 2021

Accepted: 28 January 2021

Published: 16 February 2021

Citation:

Goniewicz K and Lasota D (2021) Editorial: Advances in Road Safety

Planning.

Front. Sustain. Cities 3:652953. doi: $10.3389 /$ frsc. 2021.652953 pillars of "Engineering, Enforcement, and Education." Both public health and road safety teams have access to data and evidence. Sharing this can improve the effectiveness of actions and set evidence-based objectives. Joint evaluations can identify whether activities are having an impact across a broad range of health issues (Goniewicz et al., 2016; Najaf et al., 2018).

Promoting healthy and sustainable transport options prevents the negative effects of current transport patterns on human health, such as those caused by air pollution and physical inactivity. Cooperation among sectors and high-level political commitment are crucial to ensure that health issues are considered when transport policies are made (World Health Organization, 2020).

Taken together, the papers of our collection show research gaps in the many areas, but they also indicate solutions that can be implemented and contribute to improving security. Examples of efforts are presented in following articles: (i) Starkey and Charlton (ii) Khayesi (iii) Wang et al.. This depends upon the different perspectives of researchers and decision-makers.

Research conducted in many developed countries has confirmed that the number of fatalities and serious injuries resulting from road accidents could be reduced by applying an integrated approach to road safety (Mendoza et al., 2017; Marshall, 2018; Jamroz et al., 2019; Lasota et al., 2019, 2020). Such activities should be carried out within all facets of the road safety system, including transport, health care, supervision, law, and spatial planning.

After evaluating the effectiveness of actions aimed at improving road safety, it was concluded that many strategies and programs undertaken around the world contributed to the reduction of accidents and their consequences. 
In order to improve road safety and reduce the severity of injuries resulting from accidents, it is necessary to recognize the seriousness of road accidents as an urgent issue (Cassarino and Murphy, 2018). This requires cooperation among politicians, experts and practitioners from research and university centers dealing with road safety, road administration, emergency services, police and the media.

An essential tool for the effective prevention of injuries resulting from road accidents is the adoption of a systemic approach, which includes the following elements: problem identification, formulation of goals, preparation of programs and strategies, and monitoring the efficiency of the activities carried out (Yue et al., 2019).

Strategies and programs aimed at improving road safety should include the following actions: reduction of exposure to the hazards of accidents; prevention of accidents; reduction of injuries resulting from accidents; reduction of the effects of injuries through the improvement of post-treatment medical care (Goniewicz et al., 2016).

\section{REFERENCES}

Cassarino, M., and Murphy, G. (2018). Reducing young drivers' crash risk: are we there yet? An ecological systems-based review of the last decade of research. Transport. Res. F Traffic Psychol. Behav. 56, 54-73. doi: 10.1016/j.trf.2018.04.003

Goniewicz, K., Goniewicz, M., Pawłowski, W., and Fiedor, P. (2016). Road accident rates: strategies and programmes for improving road traffic safety. Eur. J. Trauma. Emerg. Surg. 42, 433-438. doi: 10.1007/s00068-015-0544-6

Jamroz, K., Budzyński, M., Romanowska, A., Zukowska, J., Oskarbski, J., and Kustra, W. (2019). Experiences and challenges in fatality reduction on polish roads. Sustainability 11:959. doi: 10.3390/su11040959

Lasota, D., Goniewicz, M., Kosson, D., Ochal, A., Krajewski, P., Tarka, S., et al. (2019). The effect of ethyl alcohol on the severity of injuries in fatal pedestrian victims of traffic crashes. PLoS ONE 14:e0221749. doi: 10.1371/journal.pone.0221749

Lasota, D., Goniewicz, M., Kosson, D., Ochal, A., Krajewski, P., Tarka, S., et al. (2020). Effects of ethyl alcohol on injuries severity according to injury severity scales in pedestrian fatal injury in traffic crashes. Int. J. Inj. Contr. Saf. Promot. 27, 112-120. doi: 10.1080/17457300.2019.1665551

Marshall, W. E. (2018). Understanding international road safety disparities: why is Australia so much safer than the United States?. Accid. Anal. Prev. 111, 251-265. doi: 10.1016/j.aap.2017.11.031

Mendoza, A. E., Wybourn, C. A., Mendoza, M. A., Cruz, M. J., Juillard, C. J., and Dicker, R. A. (2017). The worldwide approach to Vision Zero: implementing road safety strategies to eliminate traffic-related fatalities. Curr. Traum. Rep. 3, 104-110. doi: 10.1007/s40719-017-0085-z

Najaf, P., Isaai, M. T., Lavasani, M., and Thill, J. C. (2017). Evaluating traffic safety policies for developing countries based on equity considerations. J. Transport. Safety Security 9(Suppl. 1), 178-203. doi: 10.1080/19439962.2016.1230163
In order to improve road safety, it is necessary to strive for the change of legal provisions regarding the equipment of a car, and to intensify the educational activity in the field of first aid. As well as this, children of all ages should be exposed to intensive educational activities related to promoting road safety.

Undoubtedly there is still much research to be conducted in this area and the relevance of road safety is as great now as it ever was in addressing the challenges of sustainable and health. Nevertheless, only a solid assessment of costs and expected impacts can guide the design and implementation of a safe transport which represents an interplay between health and sustainable.

\section{AUTHOR CONTRIBUTIONS}

KG: conceptualization. KG and DL: writing-original draft preparation. All authors contributed to the article and approved the submitted version.

Najaf, P., Thill, J. C., Zhang, W., and Fields, M. G. (2018). City-level urban form and traffic safety: a structural equation modeling analysis of direct and indirect effects. J. Trans. Geography 69, 257-270. doi: 10.1016/j.jtrangeo.2018. 05.003

Pauer, G. (2017). Development potentials and strategic objectives of intelligent transport systems improving road safety. Trans. Telecommun. J. 18, 15-24. doi: 10.1515/ttj-2017-0002

Pawłowski, W., Goniewicz, K., Schwebel, D. C., Shen, J., and Goniewicz, M. (2019). Road traffic injuries in Poland: magnitude and risk factors. Eur. J. Trauma. Emerg. Surg. 45, 815-820. doi: 10.1136/injuryprevention-2018-safe ty. 130

World Health Organization (2020). Available online at: http://www.euro.who.int/ en/health-topics/environment-and-health/Transport-and-health

Yue, L., Abdel-Aty, M. A., Wu, Y., and Farid, A. (2019). The practical effectiveness of advanced driver assistance systems at different roadway facilities: system limitation, adoption, and usage. IEEE Transact. Intelligent Transp. Syst. 21:3859-3870. doi: 10.1109/TITS.2019.2935195

Conflict of Interest: The authors declare that the research was conducted in the absence of any commercial or financial relationships that could be construed as a potential conflict of interest.

Copyright (c) 2021 Goniewicz and Lasota. This is an open-access article distributed under the terms of the Creative Commons Attribution License (CC BY). The use, distribution or reproduction in other forums is permitted, provided the original author(s) and the copyright owner(s) are credited and that the original publication in this journal is cited, in accordance with accepted academic practice. No use, distribution or reproduction is permitted which does not comply with these terms. 